\title{
Docking Studies, Synthesis, and Evaluation of Antioxidant Activities of $N$-Alkylated, 1,2,4-Triazole, 1,3,4-Oxa-, and Thiadiazole Containing the Aminopyrazolopyridine Derivatives
}

\author{
Yasser K. Abdelmonem, Farag A. El-Essawy*, Saeda A. Abou El-Enein, Mona M. El-Sheikh-Amer \\ Department of Chemistry, Faculty of Science, Minoufiya University, Shibin El Kom, Egypt \\ Email: *farag.eleswi@science.menofia.edu.eg
}

Received June 27, 2013; revised August 5, 2013; accepted August 21, 2013

Copyright (C) 2013 Yasser K. Abdelmonem et al. This is an open access article distributed under the Creative Commons Attribution License, which permits unrestricted use, distribution, and reproduction in any medium, provided the original work is properly cited.

\begin{abstract}
Synthesis of some 1,3,4- thia-, oxadiazol and 1,2,4 triazole incorporated the biologically active and the pyrazolopyridine derivative. Molecular modeling and docking of the active compounds into AKR1C3 complexed with its bound inhibitor indomethacin using Molsoft ICM 3.4-8C program were performed in order to predict the affinity and orientation of the synthesized compounds at the active site.
\end{abstract}

Keywords: Pyrazolopyridine; Biologically Active; Molecular Modeling and Inhibitor

\section{Introduction}

$1 H$-Pyrazolo[3,4- $b]$ pyridines comprise a very interesting class of compounds because of their significant and versatile biological and pharmacological activities, such as antimalarial [1] antiproliferative [2] antimicrobial [3-5] inhibition of cyclin-dependent kinases [6] and cardiovascular [7-9] antiviral [10-12] and antileishmanial [13] activities. Pyrazole fused pyridines and pyrimidines are known to possess a wide range of biological activity. Specifically pyrazolopyridines exhibit antitubercular, anxiolytic [14].

It has been reported that certain compounds bearing 1,3,4-oxa-, thiadiazole, and 1,2,4-triazole nucleus possess significant anti-inflammatory activity $[15,16]$. Also, in view of these reports and in continuation of our recent work on the pyrazolo $[3,4-b]$ pyridine derivatives, to synthesize a new heterocyclic compounds $[17,18]$, we reported here the synthesis of a number of new alkylated 4,6-dimethyl- $1 H$-pyrazolo[3,4- $b$ ]pyridine-3-amine, formation of 1,2,4-triazoles, 1,3,4-oxadiazole, and 1,3,4-thiadiazoles.

Design of drug targets containing two carboxylic groups appropriately attached to the opposite sides of the aromatic fragment (e.g., naphthalene ring) as shown by our synthesized compounds to interact with the active

${ }^{*}$ Corresponding author. site hydrophobic pocket while the first carboxylate may occupy the oxyanion hole and the second forms H-bonds with oxygen of coenzyme's diphosphate moiety will be a good rational for potent inhibitors.

\section{Material and Methods}

\subsection{Experimental}

Melting points were determined on a Buchi melting point. IR spectra were recorded with a Perkin-Elmer model 1720 FTIR (KBr), 1H NMR spectra were recorded with Bruker AC 250 FT NMR spectrometer at $250 \mathrm{MHz}$ with TMS as an internal standard. EIMS and FABMS spectra were recorded with a Finnigen MAT $312=$ AMD. The microanalyses were performed at the microanalytical unit, Cairo University.

Ethyl 2-(3-amino-4,6-dimethyl-1H-pyrazolo[3,4-b] pyridin-1-yl)acetate (2). To a stirred suspension of pyrazolopyridine $1(0.81 \mathrm{~g}, 5 \mathrm{mmol})$ in dry DMF $(10 \mathrm{~mL})$ contaning $\mathrm{K}_{2} \mathrm{CO}_{3}(0.67 \mathrm{~g}, 5 \mathrm{mmol})$, the ethyl chloroacetae $(0.61 \mathrm{~g}, 5 \mathrm{mmol})$ was added dropwise. The reaction mixture was stirred at room temperature for an additional 13 $\mathrm{h}$ and then poured into ice cold water with stirring. The obtained solid product was collected by the filtration, washed with water and recrystallized from ethanol to afford the pale yellow crystals of ester 2. $(0.77 \mathrm{~g}, 95 \%)$, m.p. $127^{\circ} \mathrm{C}-129^{\circ} \mathrm{C}$. IR $\left(\mathrm{KBr}, v_{\max }, \mathrm{cm}^{-1}\right): 3316\left(\mathrm{NH}_{2}\right)$, 
2923, 2853 (CH aliphatic), $1722(\mathrm{C}=\mathrm{O}), 1596(\mathrm{C}=\mathrm{N}) \cdot{ }^{1} \mathrm{H}$ NMR $\left(\mathrm{CDCl}_{3}\right), \delta$, ppm: $1.13\left(3 \mathrm{H}, \mathrm{t}, J=7 \mathrm{~Hz}, \underline{\mathrm{CH}}_{3} \mathrm{CH}_{2}\right)$, $4.22\left(2 \mathrm{H}, \mathrm{q}, J=13 \mathrm{~Hz}, \mathrm{CH}_{3} \mathrm{CH}_{2}\right), 2.70\left(3 \mathrm{H}, \mathrm{s}, \mathrm{CH}_{3}\right), 2.79$ $\left(3 \mathrm{H}, \mathrm{s}, \mathrm{CH}_{3}\right), 5.09\left(2 \mathrm{H}, \mathrm{s}, \mathrm{CH}_{2}\right), 6.57(1 \mathrm{H}, \mathrm{s}, \mathrm{H}-5), 7.14$ $\left(2 \mathrm{H}, \mathrm{bs}, \mathrm{NH}_{2}\right)$. Mass spectrum, m/z (I, \%): $249\left[\mathrm{M}^{+}+1\right]$ (35), $248\left[\mathrm{M}^{+}\right]$(100), 161 (70), 131 (16). Found, \%: C 58.05; $\mathrm{H}$ 6.50; $\mathrm{N}$ 22.57. $\mathrm{C}_{12} \mathrm{H}_{16} \mathrm{~N}_{4} \mathrm{O}_{2}$ Calculated, \%: C 57.99; H 6.22; N 22.32.

2-(3-Amino-4,6-dimethyl-1H-pyrazolo[3,4-b] pyridin-1-yl) acetohydrazide (3). To a suspension of ester 2 $(1.24 \mathrm{~g}, 5 \mathrm{mmol})$ in ethanol $(15 \mathrm{ml})$, an excess of hydrazine hydrate $(4 \mathrm{ml})$ was added. The reaction mixture was refluxed for $4 \mathrm{~h}$, cooled, the solid product was collected by filteration, deried, and recrystalized from methanol to give the pale yellow crystals of compound 3 (0.91 g, $77 \%)$ mp $150^{\circ} \mathrm{C}-152^{\circ} \mathrm{C} \mathrm{IR}(\mathrm{KBr})\left(\mathrm{cm}^{-1}\right), v=3343-$ $3202\left(\mathrm{NHNH}_{2}\right), 2938,2892(\mathrm{CH}$ aliphatic $), 1660(\mathrm{C}=\mathrm{O})$, $1589(\mathrm{C}=\mathrm{N}) .{ }^{1} \mathrm{H}$ NMR (DMSO-d $), \delta, \mathrm{ppm}: 2.45(3 \mathrm{H}, \mathrm{s}$, $\left.\mathrm{CH}_{3}\right), 2.51\left(3 \mathrm{H}, \mathrm{s}, \mathrm{CH}_{3}\right), 4.98\left(2 \mathrm{H}, \mathrm{s}, \mathrm{CH}_{2}\right), 5.12(2 \mathrm{H}, \mathrm{bs}$, $\left.\underline{\mathrm{NH}}_{2} \mathrm{NH}\right), 6.54(1 \mathrm{H}, \mathrm{s}, \mathrm{CH}-5), 6.79\left(2 \mathrm{H}, \mathrm{bs}, \mathrm{NH}_{2}\right), 9.16$ $\left(1 \mathrm{H}, \mathrm{bs}, \mathrm{NH}_{2} \mathrm{NH}\right)$. Mass spectrum, m/z $(I, \%): 234\left[\mathrm{M}^{+}\right]$ (8), 252 (25), 219 (23), 175 (100). Found, \%: C 51.27; H 6.02; $\mathrm{N} \mathrm{35.88.} \mathrm{C}_{10} \mathrm{H}_{14} \mathrm{~N}_{6} \mathrm{O}$ Calculated, \%: C 51.13; $\mathrm{H}$ $5.88 ; \mathrm{N} 35.47$.

5-((3-amino-4,6-dimethyl-1H-pyrazolo[3,4-b] pyridin-1-yl)methyl)-1,3,4-oxadiazole-2-thiol (4). Hydrazid 3 (0.94 g, $4 \mathrm{mmol})$ and $\mathrm{CS}_{2}(0.3 \mathrm{~g}, 4 \mathrm{mmol})$ were added to a solution of $\mathrm{KOH}(0.22 \mathrm{~g}, 4 \mathrm{mmol})$ in water $(10 \mathrm{ml})$ and ethanol $(10 \mathrm{ml})$. The reaction mixture was refluxed for $4 \mathrm{~h}$. After evaporation under reduced pressure, a solid was obtained. This was dissolved in water and acidified with conc. $\mathrm{HCl}$. The precipitate was filtered, washed with water, and recrystallized from methanol to give colorless powder, yield $0.72 \mathrm{~g}, 65 \%, \mathrm{mp} 230^{\circ} \mathrm{C}$ $233^{\circ} \mathrm{C}(\mathrm{MeOH})$. IR spectrum (thin layer), $v, \mathrm{~cm}^{-1}: 2784$, $2725(\mathrm{~S}-\mathrm{H}), 1566(\mathrm{C}=\mathrm{N}) .{ }^{1} \mathrm{H}$ NMR spectrum $(300 \mathrm{MHz}$, DMSO-d $\left.d_{6}\right), \delta, \operatorname{ppm}(J, \mathrm{~Hz}): 2.45\left(3 \mathrm{H}, \mathrm{s}, \mathrm{CH}_{3}\right), 2.52(3 \mathrm{H}$, $\left.\mathrm{s}, \mathrm{CH}_{3}\right), 4.18\left(\mathrm{~s}, 2 \mathrm{H}, \mathrm{CH}_{2}\right), 6.74(1 \mathrm{H}, \mathrm{s}, \mathrm{CH}-5), 6.87(2 \mathrm{H}$, bs, $\left.\mathrm{NH}_{2}\right) 13.82$ (brs, 1H, SH). ${ }^{13} \mathrm{C}$ NMR spectrum $(75.5$ $\left.\mathrm{MHz}, \mathrm{DMSO}-d_{6}\right), \delta$, ppm: 15.13, $19.62\left(2 \mathrm{CH}_{3}\right), 33.30$ $\left(\mathrm{CH}_{2}\right), 115.12$, 125.17, 128.59, 128.79, 129.37, 129.72, 135.84, 144.28 (Ar-C). Mass spectrum (EI, $70 \mathrm{ev),} \mathrm{m} / \mathrm{z}$

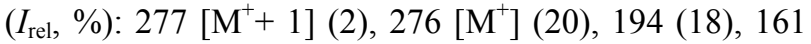
(24), 129 (22), 44 (74), 28 (100). Found, \%: C, 47.81, H, 4.38, N, 30.41. $\mathrm{C}_{11} \mathrm{H}_{12} \mathrm{~N}_{6}$ OS.Calculated, \%: C, 47.32; H, $4.31 ; \mathrm{N}, 30.29$.

4,6-dimethyl-1-((5-(alkylthio)-1,3,4-oxadiazol-2-yl) methyl)-1H-pyrazolo[3,4-b]pyridin-3-amine (5a-c). To a stirred suspension of oxadiazol thion $4(1 \mathrm{mmol})$ in dry DMF (10 ml), sodium hydride (0.04 g, $1 \mathrm{mmol}, 60 \%$ dispersion oil) was added. When liberation of hydrogen had ceased $(1.5 \mathrm{~h})$, the appropriate alkyl reagent (ethyl-, methyl iodide and benzylchloride) was added in dropwise, and the reaction mixture was stirred at room tem- perature for 10 - $15 \mathrm{~h}$. The solvent was removed under reduced pressure and the residue was triturated with cold water with stirring for $2-5 \mathrm{~h}$, the products was filtered off, deride and recrystallized with ethanol to give 5a-c.

1-((5-(Ethylthio)-1,3,4-oxadiazol-2-yl)methyl)-4,6-dimethyl-1H-pyrazolo[3,4-b]pyridin-3-amine (5a). Colorless crystals, yield $0.19 \mathrm{~g} 61 \%$, mp $139^{\circ} \mathrm{C}-140{ }^{\circ} \mathrm{C} ;{ }^{1} \mathrm{H}$ NMR spectrum $\left(300 \mathrm{MHz}, \mathrm{CDCl}_{3}\right), \delta, \operatorname{ppm}(J, \mathrm{~Hz}): 0.93$ $\left(3 \mathrm{H}, \mathrm{t}, \mathrm{J}=7.0 \mathrm{~Hz}, \mathrm{CH}_{3} \mathrm{CH}_{2}\right), 2.45\left(3 \mathrm{H}, \mathrm{s}, \mathrm{CH}_{3}\right), 2.53(3 \mathrm{H}$, $\left.\mathrm{s}, \mathrm{CH}_{3}\right), 3.11\left(2 \mathrm{H}, \mathrm{q}, J=7.1, \mathrm{SCH}_{2} \mathrm{CH}_{3}\right), 4.87(2 \mathrm{H}, \mathrm{s}$, $\left.\mathrm{N}-\mathrm{CH}_{2}\right), 6.88(1 \mathrm{H}, \mathrm{s}, \mathrm{H}-5), 7.02\left(2 \mathrm{H}, \mathrm{bs}, \mathrm{NH}_{2}\right)$. Mass spectrum (EI, $70 \mathrm{ev}), m / z\left(I_{\text {rel }}, \%\right): 304\left[\mathrm{M}^{+}\right](20), 290$ $\left[\mathrm{M}-\mathrm{CH}_{3}\right], 148$ (100). Found, \%: C, 51.30; H, 5.30; N, 27.16. $\mathrm{C}_{13} \mathrm{H}_{16} \mathrm{~N}_{6} \mathrm{OS}$. Calculated, \%: C, 51.15; H, 5.14; N, 27.09 .

4,6-Dimethyl-1-((5-(methylthio)-1,3,4-oxadiazol-2-y l)methyl)-1H-pyrazolo[3,4-b]pyridin-3-amine (5b). Colorless crystals, yield $0.24 \mathrm{~g}, 77 \%$, mp $160{ }^{\circ} \mathrm{C}-162{ }^{\circ} \mathrm{C} ;{ }^{1} \mathrm{H}$ NMR spectrum $\left(300 \mathrm{MHz}, \mathrm{CDCl}_{3}\right), \delta, \operatorname{ppm}(J, \mathrm{~Hz}): 2.33$ $\left(3 \mathrm{H}, \mathrm{s}, \mathrm{CH}_{3}\right), 2.49\left(3 \mathrm{H}, \mathrm{s}, \mathrm{SCH}_{3}\right), 2.54\left(3 \mathrm{H}, \mathrm{s}, \mathrm{CH}_{3}\right), 4.55$ $\left(2 \mathrm{H}, \mathrm{s}, \mathrm{N}-\mathrm{CH}_{2}\right), 6.67(1 \mathrm{H}, \mathrm{s}, \mathrm{H}-5), 7.25\left(2 \mathrm{H}, \mathrm{bs}, \mathrm{NH}_{2}\right)$. Mass spectrum (EI, $70 \mathrm{ev}), m / z\left(I_{\text {rel }}, \%\right): 290\left(\mathrm{M}^{+}, 43\right)$, 148 (100). Found, \%: C, 49.64; H, 4.86; N, 28.95. $\mathrm{C}_{12} \mathrm{H}_{14} \mathrm{~N}_{6} \mathrm{OS}$. Calculated, \%: C, 49.45; H, 4.52; N, 28.65.

1-((5-(benzylthio)-1,3,4-oxadiazol-2-yl)methyl)-4,6-dimethyl-1H-pyrazolo[3,4-b]pyridin-3-amine (5c). Colorless powder, yield $0.31 \mathrm{~g}, 78 \%$, mp $202^{\circ} \mathrm{C}-204^{\circ} \mathrm{C} ; \mathrm{H}^{1}$ NMR spectrum $\left(300 \mathrm{MHz}, \mathrm{CDCl}_{3}\right), \delta$, ppm $(J, \mathrm{~Hz}): 2.53$, $2.64\left(6 \mathrm{H}, 2 \mathrm{~s}, 2 \mathrm{CH}_{3}\right), 4.40\left(2 \mathrm{H}, \mathrm{s}, \mathrm{SCH}_{2} \mathrm{Ph}\right), 4.55(2 \mathrm{H}, \mathrm{s}$, $\left.\mathrm{CH}_{2}\right), 6.32$ (1H, s, H-5), 6.67 - 7.47 (5H, m, Ph). Mass spectrum (EI, $70 \mathrm{ev}), m / z\left(I_{\mathrm{rel}}, \%\right): 366\left[\mathrm{M}^{+}\right], 289$ (55), 275 (34), 91 (100). Found, \%: C, 59.00; H, 4.95; N, 22.93. $\mathrm{C}_{18} \mathrm{H}_{18} \mathrm{~N}_{6} \mathrm{OS}$. Caculated, \%: C, 58.87; H, 4.34; N, 22.86 .

2-(2-(3-Amino-4,6-dimethyl-1H-pyrazolo[3,4-b] pyridin-1-yl)acetyl)-N-phenylhydrazinecarbothioamide (6). To suspension of acid hydrazide $3(2.34 \mathrm{~g}, 10 \mathrm{mmol})$ in absolute ethanol $(20 \mathrm{~mL})$, PhNCS (1.35 g, $10 \mathrm{mmol})$ was added. The reaction mixture was heated under reflux for $6 \mathrm{~h}$. The product that separated on cooling was filtered off, washed with ethanol dried and recrystallized from methanol to give a colorless crystals of compound $\mathbf{6}$, yield, 3.46 g, $94 \%$, m.p. $173^{\circ} \mathrm{C}-175^{\circ} \mathrm{C}$. IR (KBr, $v_{\max }$, $\left.\mathrm{cm}^{-1}\right): 3336-3244\left(\mathrm{NH}, \mathrm{NH}_{2}\right), 4035,2978,2886(\mathrm{CH}$ aliphatic), $1697(\mathrm{CONH}), 1593(\mathrm{C}=\mathrm{N}), 1195-1130$ $(\mathrm{C}=\mathrm{S}) .{ }^{1} \mathrm{H} \mathrm{NMR}\left(\mathrm{CDCl}_{3}\right), \delta, \mathrm{ppm}: 2.55\left(3 \mathrm{H}, \mathrm{s}, \mathrm{CH}_{3}\right)$, $2.68\left(3 \mathrm{H}, \mathrm{s}, \mathrm{CH}_{3}\right), 4.95\left(2 \mathrm{H}, \mathrm{s}, \mathrm{CH}_{2}\right), 6.98(1 \mathrm{H}, \mathrm{s}, \mathrm{H}-5)$, 7.93-8.54 (7H, m, NH, ph), 8.77 (1H, s, N=CH), 9.07 (1H, bs, CSNH), 10.43 (1H, bs, CONH). Mass spectrum, m/z (I, \%): $270\left[\mathrm{M}^{+}+1,20\right], 269\left[\mathrm{M}^{+}, 70\right], 192$ (35), 240 $\left[\mathrm{M}^{+}\right]$(100), 161 (70), 131 (16). Found, \%: C 55.27; H 5.18; N 26.54. $\mathrm{C}_{17} \mathrm{H}_{19} \mathrm{~N}_{7} \mathrm{OS}$ Calculated, \%: C 55.33; $\mathrm{H}$ $5.15 ; \mathrm{N} 26.57$.

5-((3-amino-2-yl-methyleneamino)-4,6-dimethyl-1H 
-pyrazolo[3,4-b]pyridin-1-yl)methyl)- $N$-phenyl-1,3,4-t hiadiazol-2-amine (7). The phenylhydrazinecarbothioamide 6 (1.34 g, $5 \mathrm{mmol})$ was added gradually with stirring to cold conc. $\mathrm{H}_{2} \mathrm{SO}_{4}(10 \mathrm{ml})$ during $10 \mathrm{~min}$. The mixture was further stirred for another $2 \mathrm{~h}$ in an ice bath. The solid separated out was filtered, washed with water, dried and recrystallized from methanol to give a yellow crystals of compound 7, yield, $(2.95$ g, $84 \%)$, m.p. $190^{\circ} \mathrm{C}$ $-192^{\circ} \mathrm{C}$. IR $\left(\mathrm{KBr}, v_{\max }, \mathrm{cm}^{-1}\right): 3316-3285(\mathrm{NH}), 2955$ 2933 (CH aliphatic), $1598(\mathrm{C}=\mathrm{N}) .{ }^{1} \mathrm{H}$ NMR $\left(\mathrm{CDCl}_{3}\right), \delta$, ppm: $2.51\left(3 \mathrm{H}, \mathrm{s}, \mathrm{CH}_{3}\right), 2.64\left(3 \mathrm{H}, \mathrm{s}, \mathrm{CH}_{3}\right), 5.33(2 \mathrm{H}, \mathrm{s}$, $\left.\mathrm{CH}_{2}\right), 6.33(1 \mathrm{H}, \mathrm{s}, \mathrm{H}-5), 7.21\left(2 \mathrm{H}, \mathrm{bs}, \mathrm{NH}_{2}\right) 7.55-7.76$ $(6 \mathrm{H}, \mathrm{m}, \mathrm{ph}), 11.55(1 \mathrm{H}, \mathrm{bs}, \mathrm{NHPh})$. Mass spectrum, $\mathrm{m} / \mathrm{z}$ (I, \%): $352\left[\mathrm{M}^{+}+1\right]$ (35), $351\left[\mathrm{M}^{+}\right](100), 161(70), 131$ (16). Found, \%: C 58.01; H 4.88; N 27.90. $\mathrm{C}_{17} \mathrm{H}_{17} \mathrm{~N}_{7} \mathrm{~S}$ Calculated, \%: C 58.17; H 4.74; N 27.72.

5-((3-amino-2-yl-methyleneamino)-4,6-dimethyl-1H -pyrazolo[3,4-b]pyridin-1-yl)methyl)-4-phenyl-4H-1,2, 4-triazole-3-thiol (8). A suspension of thiosemicarbazide $8(2.68 \mathrm{~g}, 10 \mathrm{mmol})$ in ethanol $(50 \mathrm{ml})$ was dissolved in $4 \mathrm{~N}$ aqueous sodium hydroxide $(50 \mathrm{ml})$, resulting in the formation a clear solution. The reaction mixture was refluxed for $4 \mathrm{~h}$ on water bath, concentration, cooled, and filtered. The $\mathrm{pH}$ of the filtrate was adjusted between 5-6 with acetic acid and kept aside for $2 \mathrm{~h}$. The solid separated out was filtered, washed with water, dried and recrystallized with ethanol to give white powder of compound $8,(2.35 \mathrm{~g}, 67 \%)$, m.p. $217^{\circ} \mathrm{C}-219^{\circ} \mathrm{C}$. IR $(\mathrm{KBr}$, $\left.v_{\max }, \mathrm{cm}^{-1}\right)$ : $\left(\mathrm{NH}_{2}\right), 3022(\mathrm{CH}$ aromatic), 2955-2933 $(\mathrm{CH}$ aliphatic), $2786-2715(\mathrm{SH}), 1638(\mathrm{C}=\mathrm{N}) .{ }^{1} \mathrm{H}$ NMR $\left(\mathrm{CDCl}_{3}\right), \delta$, ppm: $2.50\left(3 \mathrm{H}, \mathrm{s}, \mathrm{CH}_{3}\right), 2.61\left(3 \mathrm{H}, \mathrm{s}, \mathrm{CH}_{3}\right)$, $5.39\left(2 \mathrm{H}, \mathrm{s}, \mathrm{CH}_{2}\right), 6.23(1 \mathrm{H}, \mathrm{s}, \mathrm{H}-5), 7.22-7.75(8 \mathrm{H}, \mathrm{m}$, $\left.\mathrm{ph}, \mathrm{NH}_{2}\right), 12.05(1 \mathrm{H}, \mathrm{bs}, \mathrm{SH})$. Mass spectrum, $\mathrm{m} / \mathrm{z}(\mathrm{I}, \%)$ : $352\left[\mathrm{M}^{+}+1\right]$ (35), $351\left[\mathrm{M}^{+}\right]$(69), 160 (35), 131 (100). Found, \%: C 58.01; H 4.88; N 27.90. $\mathrm{C}_{17} \mathrm{H}_{17} \mathrm{~N}_{7} \mathrm{~S}$ Calculated, \%: C 58.28; H 4.95; N 27.66.

5-((3-amino-4,6-dimethyl-1H-pyrazolo[3,4-b]pyridi n-1-yl)methyl)-N-phenyl-1,3,4-oxadiazol-2-amine (9): Mercuric oxide $(2.37 \mathrm{~g}, 11 \mathrm{mmol})$ was added to solution of thiosemicarbazide $6(2.69 \mathrm{~g}, 10 \mathrm{mmol})$ in methanol $(20 \mathrm{~mL})$ and the resulting mixture was refluxed for $3 \mathrm{~h}$. The precipitate mercuric sulfide was filtered off and washed with hot methanol. The filtrate on cooling gave a solid product which was filtered, dried and recrystallized from methanol to give a yellow crystals of oxadiazol 9 $(2.78$ g, $83 \%)$, m.p. $210 \mathrm{C}^{\circ}-212^{\circ} \mathrm{C}$. IR $\left(\mathrm{KBr}, v_{\max }, \mathrm{cm}^{-1}\right)$ : $3230-3205\left(\mathrm{NH}, \mathrm{NH}_{2}\right), 3055(\mathrm{CH}$ aromatic), 2944 2910 (CH aliphatic), $1635(\mathrm{C}=\mathrm{N}) .{ }^{1} \mathrm{H}$ NMR $\left(\mathrm{CDCl}_{3}\right), \delta$, ppm: $2.29\left(3 \mathrm{H}, \mathrm{s}, \mathrm{CH}_{3}\right), 2.50\left(3 \mathrm{H}, \mathrm{s}, \mathrm{CH}_{3}\right), 5.28(2 \mathrm{H}, \mathrm{s}$, $\left.\mathrm{CH}_{2}\right), 6.13(1 \mathrm{H}, \mathrm{s}, \mathrm{H}-5), 7.05-7.20\left(8 \mathrm{H}, \mathrm{m}, \mathrm{ph}, \mathrm{NH}_{2}\right)$, $10.12(1 \mathrm{H}, \mathrm{bs}, \mathrm{NHPh})$. Mass spectrum, m/z (I, \%): 336 $\left[\mathrm{M}^{+}+1\right](35), 335\left[\mathrm{M}^{+}\right](100), 147$ (70), 128 (16). Found, \%: C 60.96; H 5.25; N 29.32. $\mathrm{C}_{17} \mathrm{H}_{17} \mathrm{~N}_{7} \mathrm{O}$ Calculated, \%: C 60.88; H 5.11; N 29.24.

\subsection{Molecular Modeling Studies}

\subsubsection{Generation of Ligand and Enzyme Structures}

The crystal structure of AKR1C3 complexed with its bound inhibitor Indomethacin was downloaded through the Protein Data Bank PDB/ RCSB site and saved as *.pdb file [18].

A set of novel N-Alkylated, 1,2,4-triazole, 1,3,4-oxa-, thiadiazole and complexes containing the aminopyrazolopyridine derivatives were designed to inhibit AKR1C3. All compounds were built in ChemDraw Ultra version 8.0.3 and their energy minimized through Chem3D Ultra version 8.0.3/ MM2, Jop Type: minimum RMS Gradient of 0.100 , and saved as MDL MolFile ( $\left.{ }^{*} . \mathrm{mol}\right)$.

\subsubsection{Docking Using Molsoft ICM 3.4-8C Program}

The novel energy-minimized Indomethacin analogues were docked into the active site of AKR1C3 crystal structure using ICM-Pro software version 3.4 - 8 C. ICM-Pro scores the binding of a ligand to a receptor based upon the comparison of a series of small molecule/ protein interactions that have been reported in the PDB database. A rigid receptor/flexible ligand approach was adopted that uses five potential energy maps combining hydrophobicity, electrostatics, hydrogen bond formation, and two van-der-Waals parameters. In all cases, the program's default parameters were used.

\section{Results and Discussion}

The starting material 4,6-dimethyl- $1 H$-pyrazolo[3,4-b] pyridin-3-amine (1) was prepared according to the reported method $[19,20]$, which was alkylated, after its treatment with anhydrous potassium carbonate in dry $\mathrm{N}, \mathrm{N}$-dimethylformamide, with ethyl-2-chloroacetate to give Ethyl 2-(3-amino-4,6-dimethyl-1H-pyrazolo[3,4-b] pyridin-1-yl)acetate (2) in good yield. The ${ }^{1} \mathrm{H}$ NMR spectrum of derivative 2 showed that $\mathrm{N}-\mathrm{CH}_{2}$ of the $\mathrm{N}$-alkylated product appeared as a triplet at $\delta 1.13$ and quartet at $\delta 4.22 \mathrm{ppm}$ respectively. The latter derivative 2 was treated with hyfrazine hydrate, in ethanol on boiling, to afford the corresponding acid hydrazid. 2-(3-Amino4,6-dimethyl-1H-pyrazolo[3,4-b]pyridin-1-yl) acetohydrazide (3) was cyclized on treating with carbon disulfide, in basic medium, to give the 5-((3-amino-4,6-dimethyl1H-pyrazolo[3,4-b]pyridin-1-yl)methyl)-1,3,4-oxadiazole -2-thiol (4) which showed the broad singlet at $\delta 13.82$ ppm corresponding to the SH group in its $\mathrm{H}^{1} \mathrm{NMR}$, the latter oxadiazole $\mathbf{4}$ was also elucidated via its alkylation reactions with some alkylation agents such as methy, ethyl iodide and benzyl chloride to afford the S-alkyl derivatives 5a-c. These alkylated derivatives were elucidated by the MS spectra which showed the molecular ion peaks corresponding to its molecular wights (Scheme 1).

The acetohydrazide 3 was treated with phenylisothio- 
cyanate to give the corresponding phenylhydrazinecarbothioamide derivative $\mathbf{6}$. which was elucidated, besides the ${ }^{1} \mathrm{H}$ NMR and IR, by the mass spectrum which showed the molecular ion peak at $m / z 270$ corresponding to $\left[\mathrm{M}^{+}+1\right], m / z$ When the thiosemicarbazide $\mathbf{6}$ was reacted with concentrated sulfuric acid. 1,3,4-thiadiazole derivative 7 was obtained which showed in its ${ }^{1} \mathrm{H}$ NMR spectrum of the broadband of the $\mathrm{N} H \mathrm{Ph}$ at $\delta 11.55 \mathrm{ppm}$. The formation of the thiadiazole ring, under such acidic conditions, is due to the loss of nucleophilicity of $N-4$ as a result of its protonation leading to an increase in the nucleophilicity of the sulfur atom toward the attack of the carbonyl carbon as shown in Scheme 2. On the other hand, when the cyclization of $\mathbf{6}$ was carried out under basic conditions, the nucleophilicity of $N-4$ was enhanced and affording cyclization with carbonyl carbon atom to afford 1,2,4-triazole derivative in $67 \%$ yield. In the treatment of thiosemicarbazide 6 with mercuric oxide, the cyclization was performed, affording the 1,3,4oxadiazole derivative 9. The method of cyclization includes desulfurization by $\mathrm{HgO}$. The ${ }^{1} \mathrm{H}$ NMR of triazole 8 showed a broad singlet at $\delta 12.05$ ppm corresponding to the $\mathrm{SH}$ group. The oxadiazole derivatve 9 was elucidated besides, NMR, elemental analysis, by the mass spectrum which showed a $\left[\mathrm{M}^{+}\right]$peak, in agreement with its molecular formula (Scheme 3).

\section{Molecular Modeling Studies}

To pre-assess the anti-tumorigenic behavior of our $\mathrm{N}$ Alkylated, 1,2,4-triazole, 1,3,4-oxa-, thiadiazole and complexes containing the aminopyrazolopyridine derivatives 5(a-c) and (7-9) on a structural basis, automated docking studies were carried out using MOLSOFT ICM 3.4 - 8C program [21]. The scoring functions and hydrogen bonds formed with the surrounding amino acids are used to predict their binding modes, their binding affinities and orientation of these compounds at the active site of AKR1C3 enzyme. The protein-ligand complex was constructed based on the X-ray structure (PDB entry 1S2A) AKR1C3 with its bound inhibitor indomethacin [22].

The scoring functions of the compounds were calculated from minimized ligand protein complexes. The X-ray crystal structure of AKR1C3 reveals a substratebinding site that consists mainly of: hydrophobic aromatic amino acid side chains (Tyr24, Tyr55, Leu54, Trp227, and Phe306). An oxyanion hole, which is located at the bottom of the hydrophobic pocket, is formed by active site tyrosine (Tyr55), histidine (His117), and the coenzymes nicotinamide ring [21].

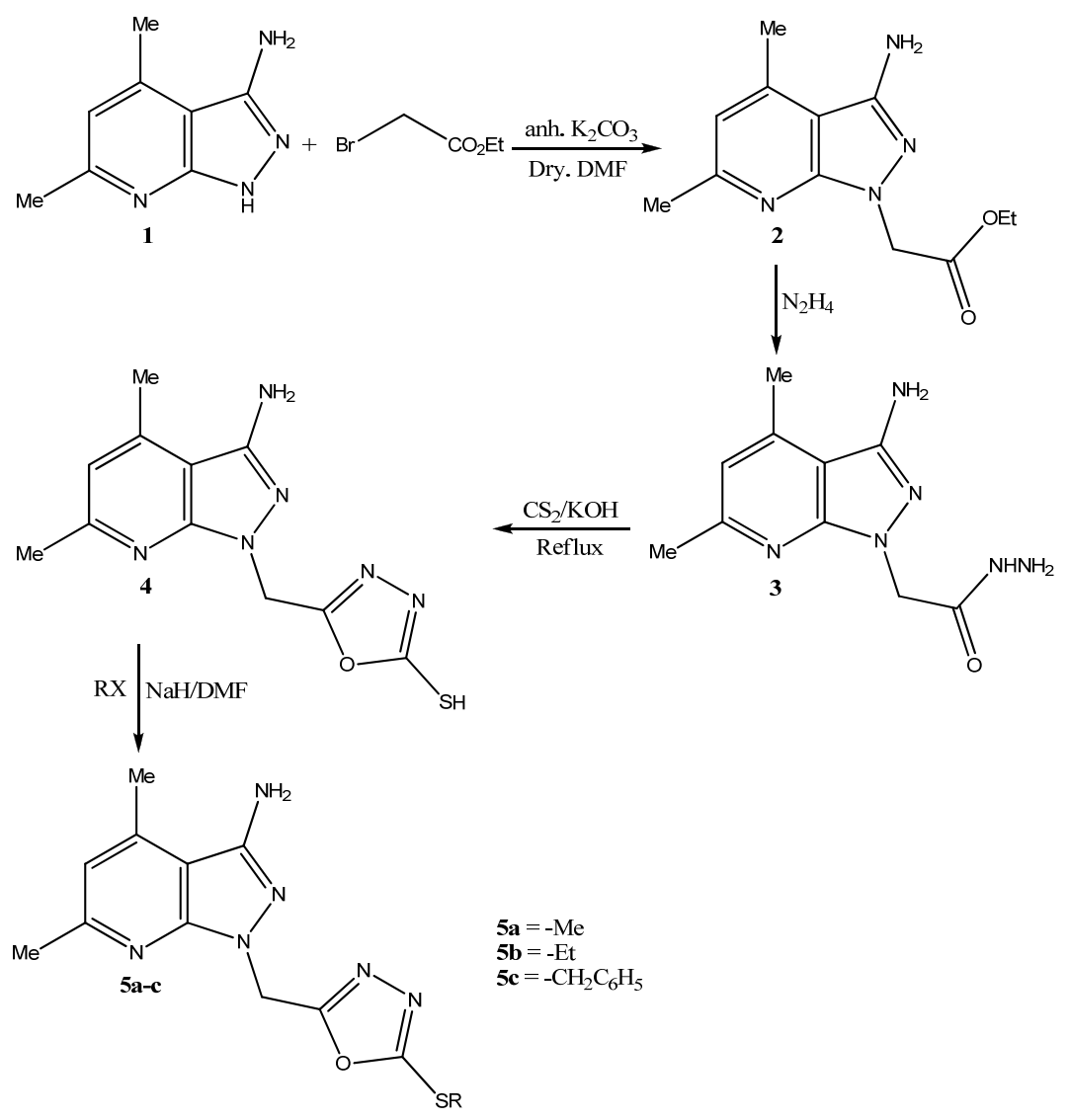

Scheme 1. Formation of the oxadiazole derivatives. 


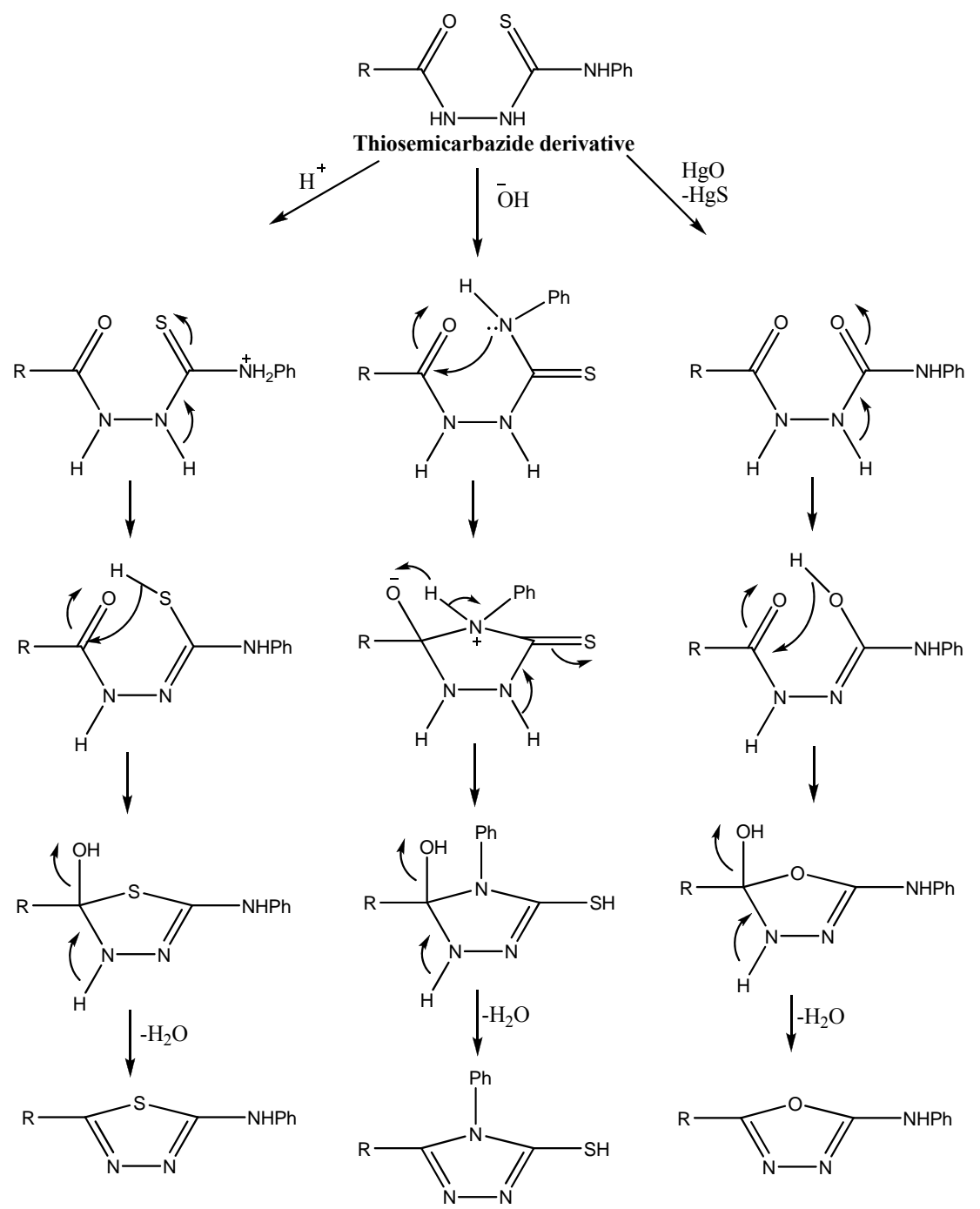

Scheme 2. Schematic investigation according to the condition applied.

In our investigation, the 3D-coordinates in X-ray crystal structure of AKR1C3 in complex with the ligand, indomethacin (PDB entry 1S2A) [21] was used as the receptor model in AKR1C3 docking simulation. The docked model of indomethacin with AKR1C3 (Figure 1) was consistent with the previously reported X-ray analysis [22] and revealed the following binding mode: The carbonyl oxygen is far away from Tyr 55 or His 117 to H-bond directly. Instead, the carboxylate group points toward and interacts with the oxygen atoms $\mathrm{O}_{1} \mathrm{n}, \mathrm{O}_{2} \mathrm{n}$ from the nicotinamide half of the $\mathrm{NADP}^{+}$diphosphate moiety, forming two hydrogen bonds, and additional $\mathrm{H}$-bond if formed between indomethacin $\mathrm{O}_{2}$ of $\mathrm{COOH}$ and $\mathrm{He}_{2}$ of Glu 222.

Our active compounds 5(a-c) and (7-9) when modeled in the active site of AKR1C3 enzyme (Table 1, Figures $\mathbf{2 , 3}$ ) revealed strong binding affinities. Their binding energies were $-67.08,-88.58,-96.73,-103.82,-88.74$ and $-97.28 \mathrm{Kcal} / \mathrm{mol}$, respectively compared to -80.45 of

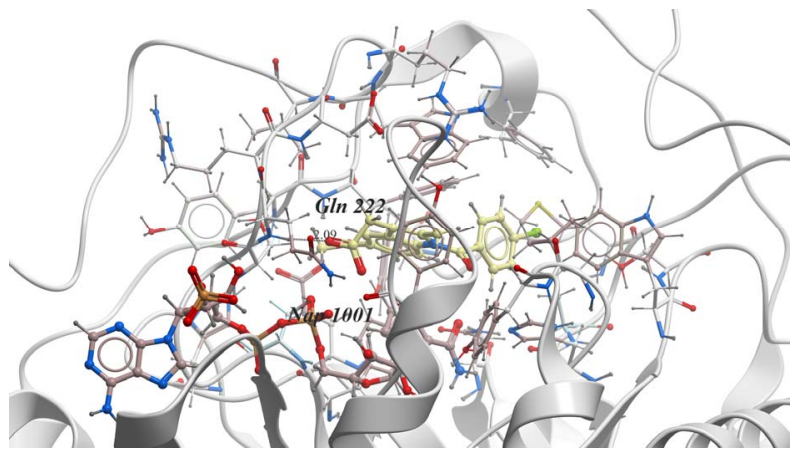

Figure 1. The proposed binding mode of original ligand indomethacin into the active binding site of AKR1C3 active site. It has ICM score of $\mathbf{- 8 0 . 4 5}$, it forms three hydrogen bonds, two of them between $\mathrm{H}$ of $\mathrm{COOH}$ and $\mathrm{O} 1 \mathrm{n}, \mathrm{O} 2 \mathrm{n}$ of Phosphate moiety of NADP. And another hydrogen bond between $\mathrm{O} 2$ of $\mathrm{COOH}$ and $\mathrm{He} 2$ of amino acid Glu222....

indomethacin. It is interesting to point out that compounds $\mathbf{5}(\mathbf{a}-\mathbf{c})$ and (7-9) are found to be very promising 
Table 1. Docking of compounds on AKR1C3.

\begin{tabular}{|c|c|c|c|c|c|}
\hline $\begin{array}{l}\text { Compound } \\
\text { number }\end{array}$ & ICM score $(\Delta \mathbf{G})$ & $\begin{array}{l}\text { No of Hydrogen } \\
\text { bonds }\end{array}$ & $\begin{array}{l}\text { Atom of ligand } \\
\text { involved }\end{array}$ & $\begin{array}{l}\text { Amino acid residues forming the } \\
\text { hydrogen bonds }\end{array}$ & $\begin{array}{l}\text { Bond length } \\
(\AA)\end{array}$ \\
\hline \multirow{4}{*}{ Indomethacin } & \multirow{3}{*}{-80.45} & \multirow{3}{*}{3} & $\mathrm{H}$ of $\mathrm{COOH}$ & Phosphate moiety of NADP....O1n & 2.36 \\
\hline & & & $\mathrm{H}$ of $\mathrm{COOH}$ & Phosphate moiety of NADP ....O2n & 1.57 \\
\hline & & & $\mathrm{O} 2$ of $\mathrm{COOH}$ & Glu222...He2 & 2.09 \\
\hline & \multirow{4}{*}{-67.08} & \multirow{3}{*}{3} & $\mathrm{~m}$ of $\mathrm{Mn} 3$ & $\operatorname{Arg} 226 \ldots h h 21$ & 2.18 \\
\hline \multirow[t]{3}{*}{$5 \mathbf{a}$} & & & $\mathrm{m}$ of $\mathrm{M}$ h2 & Tyr24...oh & 1.79 \\
\hline & & & $\mathrm{m}$ of $\mathrm{M} \mathrm{h} 3$ & Tyr24...oh & 2.68 \\
\hline & & \multirow{8}{*}{13} & $\mathrm{~m}$ of $\mathrm{M} \mathrm{n} 5$ & Ala25...hn & 2.75 \\
\hline \multirow{6}{*}{$5 \mathbf{b}$} & \multirow{7}{*}{-88.58} & & $\mathrm{~m}$ of $\mathrm{M} \mathrm{ol}$ & $\operatorname{Arg} 31 \ldots$ hh11 & 2.14 \\
\hline & & & $\mathrm{m}$ of $\mathrm{M} \mathrm{ol}$ & $\operatorname{Arg} 31 \ldots$ hh 12 & 1.58 \\
\hline & & & $\mathrm{m}$ of $\mathrm{M} \mathrm{n} 5$ & $\operatorname{Arg} 31 \ldots$ hh 21 & 2.73 \\
\hline & & & $\mathrm{m}$ of $\mathrm{M} \mathrm{n} 4$ & $\operatorname{Arg} 226 \ldots$ hh12 & 1.51 \\
\hline & & & $\mathrm{m}$ of $\mathrm{M} \mathrm{h} 2$ & Tyr24...oh & 1.86 \\
\hline & & & $\mathrm{m}$ of $\mathrm{M} \mathrm{h} 05$ & Ala25...o & 1.91 \\
\hline \multirow{8}{*}{$5 c$} & & & $\mathrm{~m}$ of M h04 & Tyr55 ...o & 2.07 \\
\hline & \multirow{7}{*}{-96.73} & \multirow{7}{*}{7} & $\mathrm{~m}$ of $\mathrm{M} \mathrm{n} 4$ & Tyr24...hh & 2.74 \\
\hline & & & $\mathrm{m}$ of $\mathrm{M} \mathrm{n} 4$ & $\operatorname{Arg} 226 \ldots$ hh12 & 1.50 \\
\hline & & & $\mathrm{m}$ of $\mathrm{Mn} 1$ & $\operatorname{Arg} 226 \ldots h h 21$ & 1.98 \\
\hline & & & $\mathrm{m}$ of $\mathrm{Mn} 4$ & $\operatorname{Arg} 226 \ldots$ hh21 & 2.54 \\
\hline & & & $\mathrm{m}$ of $\mathrm{M} \mathrm{h} 2$ & Tyr24...oh & 1.34 \\
\hline & & & $\mathrm{m}$ of $\mathrm{M} \mathrm{h} 3$ & Tyr24...oh & 2.22 \\
\hline & & & $\mathrm{m}$ of M h04 & Ser129...og & 2.37 \\
\hline \multirow{12}{*}{7} & \multirow{12}{*}{-103.82} & \multirow{12}{*}{12} & $\mathrm{~m}$ of M n5 & Ala25...hn & 1.59 \\
\hline & & & $\mathrm{m}$ of $\mathrm{M} \mathrm{n} 5$ & $\operatorname{Arg} 31 \ldots$ hh12 & 2.53 \\
\hline & & & $\mathrm{m}$ of $\mathrm{M} \mathrm{n} 6$ & $\operatorname{Arg} 31 \ldots$ hh12 & 1.69 \\
\hline & & & $\mathrm{m}$ of $\mathrm{M} \mathrm{n} 7$ & $\operatorname{Arg} 31 \ldots h h 21$ & 1.55 \\
\hline & & & $\mathrm{m}$ of $\mathrm{M} \mathrm{n} 7$ & $\operatorname{Arg} 31 \ldots$ hh22 & 2.54 \\
\hline & & & $\mathrm{m}$ of $\mathrm{M} \mathrm{n} 4$ & $\operatorname{Arg} 226 \ldots$ hh12 & 1.45 \\
\hline & & & $\mathrm{m}$ of $\mathrm{M} \mathrm{n} 4$ & Arg226...hh21 & 1.76 \\
\hline & & & $\mathrm{m}$ of $\mathrm{M} \mathrm{h} 03$ & Tyr24...oh & 1.46 \\
\hline & & & $\mathrm{m}$ of $\mathrm{M} \mathrm{h} 3$ & Tyr24...oh & 2.21 \\
\hline & & & $\mathrm{m}$ of $\mathrm{M} \mathrm{h} 12$ & Ala25 ...o & 2.62 \\
\hline & & & $\mathrm{m}$ of $\mathrm{M} \mathrm{h} 12$ & Pro26...o & 2.80 \\
\hline & & & $\mathrm{m}$ of $\mathrm{M} \mathrm{h05}$ & Tyr55...o & 1.44 \\
\hline \multirow{13}{*}{8} & \multirow{13}{*}{-88.74} & \multirow{13}{*}{19} & $\mathrm{~m}$ of M n5 & Glu222 .. He2 & 2.06 \\
\hline & & & $\mathrm{m}$ of $\mathrm{M} \mathrm{n} 6$ & Lys270...hz1 & 2.00 \\
\hline & & & $\mathrm{m}$ of $\mathrm{M} \mathrm{n} 7$ & Lys270...hz1 & 2.59 \\
\hline & & & $\mathrm{m}$ of $\mathrm{M} \mathrm{n} 5$ & Lys270...hz2 & 2.60 \\
\hline & & & $\mathrm{m}$ of $\mathrm{M} \mathrm{n} 6$ & Lys270...hz2 & 1.83 \\
\hline & & & $\mathrm{m}$ of $\mathrm{Mn} 6$ & Lys270...hz3 & 1.70 \\
\hline & & & $\mathrm{m}$ of $\mathrm{M} \mathrm{n} 7$ & Lys270...hz3 & 2.22 \\
\hline & & & $\mathrm{m}$ of $\mathrm{M} \mathrm{n} 2$ & Phosphate moiety of NADP.... h01 & 2.18 \\
\hline & & & $\mathrm{m}$ of $\mathrm{Mn} 7$ & Phosphate moiety of NADP.... h01 & 1.40 \\
\hline & & & $\mathrm{m}$ of $\mathrm{M} \mathrm{n} 6$ & Phosphate moiety of NADP.... h10 & 2.45 \\
\hline & & & $\mathrm{m}$ of $\mathrm{M} \mathrm{h03}$ & Ser $221 \ldots o$ & 2.65 \\
\hline & & & $\mathrm{m}$ of $\mathrm{M} \mathrm{h} 71$ & Phosphate moiety of NADP.... o3b & 1.80 \\
\hline & & & $\mathrm{m}$ of $\mathrm{M} \mathrm{h} 02$ & Phosphate moiety of NADP ... o $2 x$ & 2.78 \\
\hline \multirow{4}{*}{9} & \multirow{4}{*}{-97.28} & \multirow{4}{*}{4} & $\mathrm{~m}$ of $\mathrm{Mn} 5$ & Glu222...he21 & 2.39 \\
\hline & & & $\mathrm{m}$ of $\mathrm{M} \mathrm{n} 7$ & Glu222...he21 & 1.55 \\
\hline & & & $\mathrm{m}$ of $\mathrm{M} \mathrm{h} 04$ & Glu222...he12 & 1.50 \\
\hline & & & $\mathrm{m}$ of $\mathrm{M} \mathrm{h} 2$ & Tyr24...oh & 2.40 \\
\hline
\end{tabular}




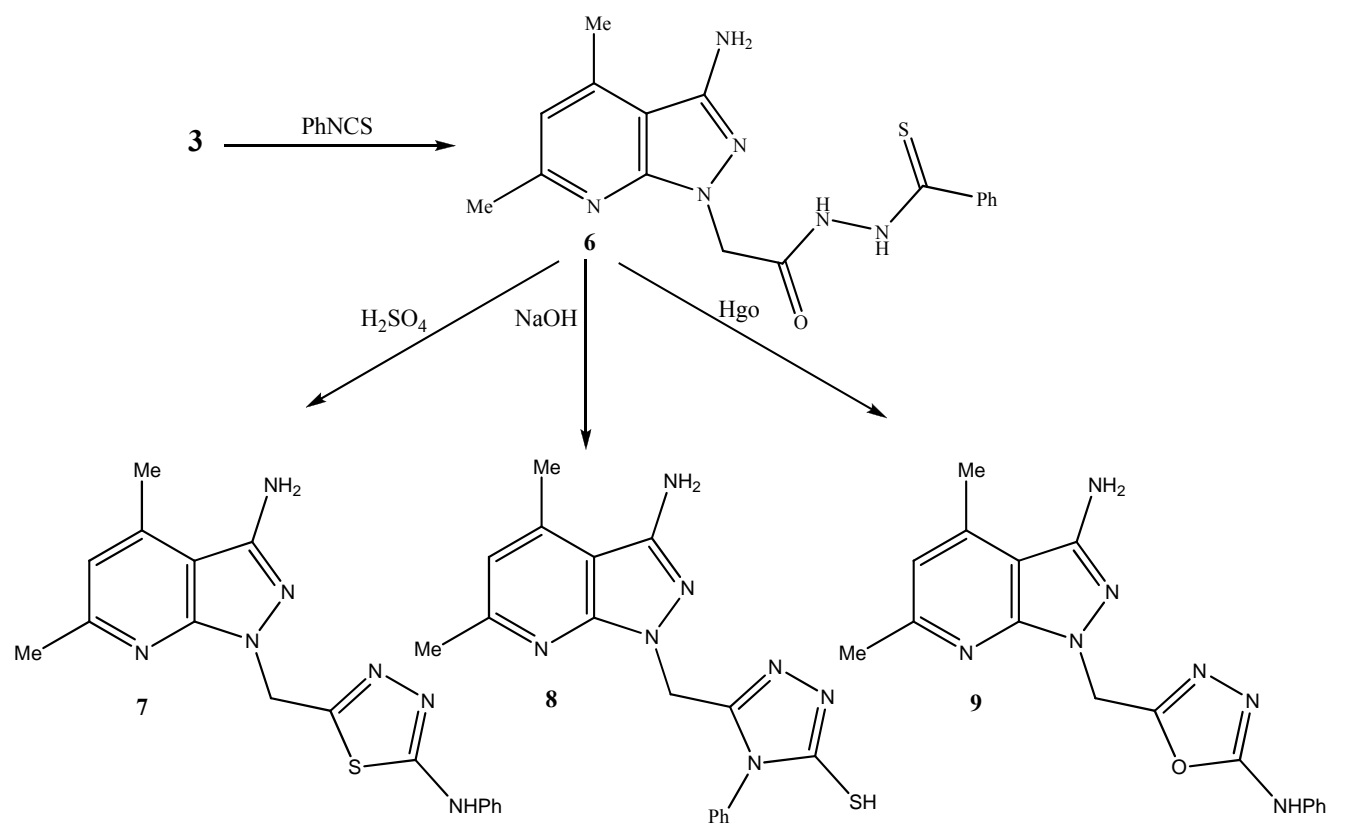

Scheme 3. crystallization of the thiosemicarbazole derivative.

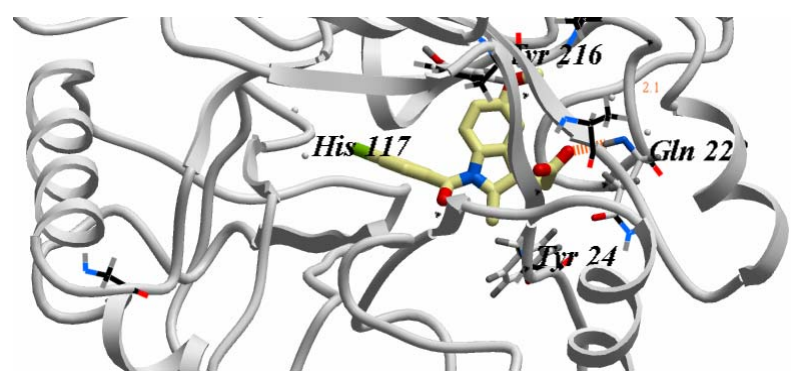

Figure 2. The proposed binding mode of $5 \mathrm{a}$ into the active binding site of AKR1C3 active site. It has ICM score of -67.08 , it forms three hydrogen bonds, two of them between $\mathrm{O} 2$ of $\mathrm{OH}$ and $\mathrm{He} 2$ and $\mathrm{He} 3$ of Tyr24 and Glu58... One hydrogen bond between $\mathrm{O3}$ of $\mathrm{SO} 2$ and $\mathrm{Hh} 1$ of amino acid Arg 226. And hydrogen bond between $\mathrm{O} 4$ of SO2 and H1n1 of Phosphate moiety of NADP....

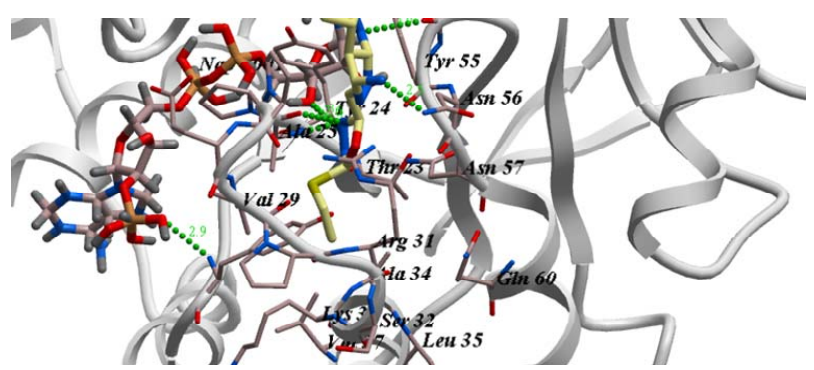

Figure 3. The proposed binding mode of $5 \mathrm{~b}$ into the active binding site of AKR1C3 active site. It has ICM score of $\mathbf{- 8 8 . 5 8}$, it forms 13 hydrogen bonds, one between $\mathrm{O1}$ of OCH3 and Ha1 of Phosphate moiety of NADP. Two hydrogen bonds between $\mathrm{O} 4$ of $\mathrm{SO} 2$ and $\mathrm{Hd} 2$ of Arg31 and H7n7 of Amide of Nicotinamide ring ... three hydrogen bonds, two of them between $\mathrm{O} 2$ of $\mathrm{OH}$ and $\mathrm{He} 2$ and $\mathrm{He} 3$ of Tyr24 and Another two hydrogen bonds is between H14, H15 of benzene ring of sulfonamide and $\mathrm{He} 2$ of amino acid Tyr55.
AKR1C3 inhibitors, as they take advantageof their ability to make $\mathrm{H}$ bond with the amino acid present in the oxyanion hole (Tyr 55 and Glu222) in the presence of the coenzyme's nicotinamide with the aromatic residues located in the hydrophobic pocket, and at the same time to $\mathrm{NADP}^{+}$diphosphate.

Using Molsoft ICM 3.4 - 8C program, molecular modelling and docking studies of the synthesized compounds into ARK1C3 complexed with its bound inhibitor indomethacin (1S2A) were performed in order to predict The binding affinities and orientations of these com- pounds at the active site. The ICM score values of $\mathbf{5}(\mathbf{a}-\mathbf{c})$ and (7-9) were $-67.08,-88.58,-96.73,-103.82,-88.74$ and $-97.28 \mathrm{Kcal} / \mathrm{mol}$, respectively compared to -80.45 of indomethacin. These derivatives will encourage researchers to help to design future anticancer agents with therapeutic potentials.

\section{REFERENCES}

[1] C. M. S. Menezes, C. M. R. Sant'Anna, C. R. Rodrigues and E. J. Barreiro, "Molecular Modeling of Novel 1H-Pyrazolo[3,4-b]pyridine Derivatives Designed as Isosters of the Antimalarial Mefloquine," Journal of Molecular Structure: THEOCHEM, Vol. 579, No. 1-3, 2002, pp. 31-39. http://dx.doi.org/10.1016/S0166-1280(01)00677-7

[2] K. Poreba, A.Oplski and J Wietrezyk, "Synthesis and Antiproliferative Activity in Vitro of New 3-Substituted aminopyrazolo[3,4-b]pyridines" Acta Poloniae Pharmaceutica, Vol. 59, No. 3, 2002, pp. 215-222.

[3] F. E. Goda, A. A. M. Abdel-Aziz and O. A. Attef, "Synthesis, Antimicrobial Activity and Conformational Analysis of Novel Substituted Pyridines: BF3-Promoted Reaction of Hydrazine with 2-Alkoxy Pyridines," Bioor- 
ganic \& Medicinal Chemistry, Vol. 12, No. 8, 2004, pp. 1845-1852. http://dx.doi.org/10.1016/j.bmc.2004.01.040

[4] F. A. Attaby and A. M. Abd El-Fattah, "A Novel Synthesis of Thienopyridine, Pyrroloquinolinothiophene, Pyrazolopyridin-3-yl Phenylthiourea and Thiazolylpyrazolopyridine Derivatives," Phosphorus, Sulfur, and Silicon and the Related Elements, Vol. 155, No. 1, 1999, pp. 253270. http://dx.doi.org/10.1080/10426509908044987

[5] M. A. A. Elneairy, F. A. Attaby and M. S. Elsayed, "Synthesis of Thiazole, Triazole, Pyrazolo[3,4-b]-Pyridinyl3-Phenylthiourea, Aminopyrazolo[3,4-b]Pyridine Derivatives and Their Biological Evaluation," Phosphorus, Sulfur, and Silicon and the Related Elements, Vol. 167, No. 1, 2000, pp. 161-179. http://dx.doi.org/10.1080/10426500008082396

[6] R. N. Misra, et al., "1H-Pyrazolo[3,4-b]pyridine Inhibitors of Cyclin-Dependent Kinases: Highly Potent 2,6-Difluorophenacyl Analogues," Bioorganic \& Medicinal Chemistry Letters, Vol. 13, No. 14, 2003, pp. 2405-2408. http://dx.doi.org/10.1016/S0960-894X(03)00381-0

[7] J. P. Stasch, , K. E. DembowskyPerzborn, E. Br. Stahl, M Schramm, "Cardiovascular Actions of a Novel NO-Independent Guanylyl Cyclase Stimulator, Bay 41-8543: In Vivo Studies," Journal of Pharmacology, Vol. 135, No. 2, 2002, pp. 344-355.

[8] G. Boerrigter, et al., "Cardiorenal and Humoral Properties of a Novel Direct Soluble Guanylate Cyclase Stimulator BAY 41-2272 in Experimental Congestive Heart Failure," Circulation, Vol. 107, 2003, pp. 686-689. http://dx.doi.org/10.1161/01.CIR.0000055737.15443.F8

[9] D. U. Bawankule, et al., "BAY 41-2272 [5-Cyclopropyl2-[1-(2-fluoro-benzyl)-1H-pyrazolo[3,4-b]pyridine-3-yl]p yrimidin-4-ylamine]-Induced Dilation in Ovine Pulmonary Artery: Role of Sodium Pump," Journal of Pharmacology and Experimental Therapeutics, Vol. 314, No. 1, 2005, pp. 207-213. http://dx.doi.org/10.1124/jpet.105.083824

[10] F. A. Attaby, A. H. H. Elghandour, M. A. Ali and Y. M. Ibrahem, "Synthesis, Reactions, and Antiviral Activity of 1-(1H-Pyrazolo[3,4-b]pyridin-5-yl)ethanone and Pyrido $\left[2^{\prime}, 3^{\prime}: 3,4\right]$ pyrazolo[5,1-c][1,2,4]triazine Derivatives," Phosphorus, Sulfur, and Silicon and the Related Elements, Vol. 181, No. 5, 2006, pp. 1087-1102. http://dx.doi.org/10.1080/10426500500326404

[11] F. A. Attaby, A. H. Elghandour, M. A. Ali and Y. M. Ibrahem, "Synthesis, Characterization, and Antiviral Activities of Pyridopyrazolotriazines," Phosphorus, Sulfur, and Silicon and the Related Elements, Vol. 182, No. 1, 2007, pp. 133-149.

http://dx.doi.org/10.1080/10426500600887313

[12] A. R. Azevedo, V. F. Ferreira, H. de Mello, L. R. LeaoFerreira, A. V. Jabor, I. C. P. P. Frugulhetti, H. S. Pereira, N. Moussatche and A. M. R. Bernardino, "Synthesis And Biological Evaluation of 1h-Pyrazolo[3,4-b]pyridine-5 Carboxylic Acids against Vaccinia Virus," Heterocyclic Communications, Vol. 8, No. 5, 2002, pp. 427-423. http://dx.doi.org/10.1515/HC.2002.8.5.427

[13] H. de Mello, A. Echevarria, A. M. Bernardino, M. Canto-Cavalheiro and L. L. Leon, “Antileishmanial Pyrazo- lopyridine Derivatives: Synthesis and Structure-Activity Relationship Analysis," Journal of Medicinal Chemistry, Vol. 47, No. 22, 2004, pp. 5427-5432. http://dx.doi.org/10.1021/jm0401006

[14] I. Sekikawa, J. Nishie, S. Tono-Oka, Y. Tanaka and S. Kakimoto, "Antituberculous Compounds. XXVIII. Synthesis of Pyrazolopyridines," Journal of Heterocyclic Chemistry, Vol. 10, No. 6, 1973, pp. 931-932. http://dx.doi.org/10.1002/jhet.5570100607

[15] M. Amir, M. S. Y Khan and M. S Zaman, "Synthesis, characterization and biological activities of substituted oxadiazole, triazole, thiadiazole and 4-thiazolidinone derivatives," Indian Journal of Chemistry B, Vol. 43B, No. 10, 2004, pp. 2189-2194.

[16] B. Tozkoparan, E. Küpeli, E. Yeşilada and M. Ertan, "Preparation of 5-aryl-3-alkylthio-1,2,4-triazoles and Corresponding Sulfones with Antiinflammatory-Analgesic Activity," Bioorganic \& Medicinal Chemistry, Vol. 15, No. 4, 2007, pp. 1808-1814. http://dx.doi.org/10.1016/j.bmc.2006.11.029

[17] F. A. El-Essawy, "Synthesis of Tetrahetrocyclic Systems Including pyrido $\left[2^{\prime}, 3^{\prime}: 3,4\right]$ pyrazolo[ $[1,5-a]$ pyrimidine Fused with Pyrazole Derivatives and Isolated with 1,3,4-oxa-, Thiadiazole, and 1,2,4-Tetrazole Derivatives" Journal of Heterocyclic Chemistry, Vol. 47, No. 2, 2010, pp. 318323.

[18] F. A. El-Essawy, "Synthesis of New Pyrido[2',3':3,4]pyrazolo[1,5-a]pyrimidines and Their Use in the Preparation of Tetraheterocyclic Systems," Synthetic Communications, Vol. 40, No. 6, 2010, pp. 877-887. http://dx.doi.org/10.1080/00397910903020783

[19] S. Gobec, P. Brožič and T. L. Rižner, "Nonsteroidal Anti-Inflammatory Drugs and Their Analogues as Inhibitors of Aldo-Keto Reductase AKR1C3: New Lead Compounds for the Development of Anticancer Agents," Bioorganic \& Medicinal Chemistry Letters, Vol. 15, No. 23, 2005, pp. 5170-5175. http://dx.doi.org/10.1016/j.bmcl.2005.08.063

[20] A. A. M. Eissa, N. A. H. Farag and G. A. H. Soliman, "Synthesis, Biological Evaluation and Docking Studies of Novel Benzopyranone Congeners for Their Expected Activity as Anti-Inflammatory, Analgesic and Antipyretic Agents," Bioorganic \& Medicinal Chemistry, Vol. 17, No. 14, 2009, pp. 5059-5070. http://dx.doi.org/10.1016/j.bmc.2009.05.073

[21] L. Labanauskas, V. Kalcas, E. Udrenaite, P. Gaidelis, A. Brukstus and V. Dauksas, "Synthesis of 3-(3,4-dimethoxyphenyl)-1 H-1,2,4-triazole-5-thiol and 2-amino-5-(3, 4-dimethoxyphenyl)-1,3,4-Thiadiazole Derivatives Exhibiting Anti-Inflammatory Activity," Pharmazie, Vol. 56, No. 8, 2001, pp. 617-619.

[22] A. L. Lovering, et al., "Crystal Structures of Prostaglandin D2 11-Ketoreductase (AKR1C3) in Complex with the Nonsteroidal Anti-Inflammatory Drugs Flufenamic Acid and Indomethacin," Cancer Research, Vol. 64, No. 5, 2004, pp. 1802-1810. http://dx.doi.org/10.1158/0008-5472.CAN-03-2847 